\title{
Cellular Tumor Antigen p53
}

National Cancer Institute

\section{Source}

National Cancer Institute. Cellular Tumor Antigen p53. NCI Thesaurus. Code C17387.

Cellular tumor antigen p53 (393 aa, 44 kDa) is encoded by the human TP53 gene. This protein plays a role in the regulation of both the cell cycle and apoptosis. 